\title{
VENTROMEDIAN FOREBRAIN DYSGENESIS FOLLOWS EARLY PRENATAL ETHANOL EXPOSURE IN MICE
}

\author{
Elizabeth A. Godin, Deborah B. Dehart, Scott E. Parnell, Shonagh K. O'Leary-Moore, and \\ Kathleen K. Sulik \\ Bowles Center for Alcohol Studies, University of North Carolina, Chapel Hill, NC 27599
}

\begin{abstract}
Ethanol exposure on gestational day (GD) 7 in the mouse has previously been shown to result in ventromedian forebrain deficits along with facial anomalies characteristic of fetal alcohol syndrome (FAS). To further explore ethanol's teratogenic effect on the ventromedian forebrain in this mouse model, scanning electron microscopic and histological analyses were conducted. For this, time mated C57Bl/6J mice were injected with $2.9 \mathrm{~g} / \mathrm{kg}$ ethanol or saline twice, at a four hour interval, on their $7^{\text {th }}$ day of pregnancy. On GD 12.5, 13 and 17, control and ethanol-exposed specimens were collected and processed for light and scanning electron microscopic analyses. Gross morphological changes present in the forebrains of ethanol-exposed embryos included cerebral hemispheres that were too close in proximity or rostrally united, enlarged foramina of Monro, enlarged or united lateral ventricles, and varying degrees of hippocampal and ventromedian forebrain deficiency. In GD 12.5 control and ethanol-exposed embryos, in situ hybridization employing probes for Nkx2.1 or Fzd8 to distinguish the preoptic area and medial ganglionic eminences (MGE) from the lateral ganglionic eminences, respectively, confirmed the selective loss of ventromedian tissues. Immunohistochemical labeling of oligodendrocyte progenitors with Olig2, a transcription factor necessary for their specification, and of GABA, an inhibitory neurotransmitter, showed ethanol-induced reductions in both. To investigate later consequences of ventromedian forebrain loss, MGE-derived somatostatin-expressing interneurons in the subpallial region of GD 17 fetal mice were examined, with results showing that the somatostatin-expressing interneurons that were present were dysmorphic in the ethanol-exposed fetuses. The potential functional consequences of this insult are discussed.
\end{abstract}

\section{Keywords}

fetal alcohol spectrum disorder; fetal alcohol syndrome; ganglionic eminence; holoprosencephaly; oligodendrocytes; interneurons

\section{INTRODUCTION}

Alcohol (ethanol) consumption during pregnancy is the leading known, yet preventable, cause of mental retardation in the western world [1]. The central nervous system (CNS)

\footnotetext{
(C) 2010 Elsevier Inc. All rights reserved.

Corresponding Author: Kathleen K. Sulik, Bowles Center for Alcohol Studies, University of North Carolina at Chapel Hill, Chapel Hill, NC 27599-7178; (919) 966-3208. mouse@ med.unc.edu.

Publisher's Disclaimer: This is a PDF file of an unedited manuscript that has been accepted for publication. As a service to our customers we are providing this early version of the manuscript. The manuscript will undergo copyediting, typesetting, and review of the resulting proof before it is published in its final citable form. Please note that during the production process errors may be discovered which could affect the content, and all legal disclaimers that apply to the journal pertain.
} 
appears to be vulnerable to ethanol insult at virtually all prenatal stages, even as early as gastrulation, a process that begins during the third week of human development [88]. While the early vulnerability to ethanol teratogenesis has been demonstrated in a number of species, Fetal Alcohol Spectrum Disorder (FASD) studies employing mice have been particularly informative. In a well-described mouse FASD model, ethanol exposure limited to gestational day 7 (GD 7), a time when gastrulation begins, has been shown to result in brain and facial abnormalities that occur in widely ranging degrees of severity $[38,82,91]$. Within the spectrum of effects, are facial features and brain anomalies that are consistent with those in full-blown Fetal Alcohol Syndrome (FAS). Notable following acute GD 7 ethanol exposure in mice is deficiency involving the ventromedian forebrain, a region that in some cases is so severely diminished that the lateral ventricles are united, forming a holosphere [38,82,91].

For the current investigation, GD 7 ethanol-induced forebrain defects in mice have been examined in greater detail than previously reported. Particular attention has been paid to the preoptic area (POA), the ganglionic eminences (GEs) and their derivative cell populations. The POA is that median forebrain region that is located just rostral to the optic recess, at the ventral boundary of the telencephalon and diencephalon [77]. Rostral to the POA is the anterior entopeduncular area (AEP). Immediately lateral in the basal forebrain are the ganglionic eminences, which are comprised of 3 distinct bilateral regions; lateral (LGE), caudal (CGE), and medial (MGE). It is from the MGEs that the globus pallidus (pallidum) arises, while the caudate nucleus and putamen (striatum) develop from the tissues of the LGEs [93]. The LGEs, CGEs and MGEs give rise to region-specific cell types that migrate tangentially into the cortical plate $[6,7,61,99,102,107]$. Among the cellular derivatives of the ganglionic eminences are interneurons, all of which co-express the inhibitory neurotransmitter $\gamma$-Aminobutyric acid (GABA), and are divisible into subpopulations based on their molecular expression patterns. Interneurons that migrate to the olfactory bulbs are derived from the LGEs $[63,101]$, while the CGEs give rise to calretinin (Cr)-expressing cortical interneurons [68]. Neuropeptide Y (NPY)-expressing interneurons come from both the CGEs and POA [37]. Finally, derived from the MGEs are both somatostatin (Sst) and parvalbumin (Pv)-expressing cortical interneurons [24,102,108].

Regarding the MGEs, it has recently been shown that the Sst-expressing interneurons arise from the dorsal MGE and that the ventral MGE gives rise to the Pv-expressing cells $[33,34,104,109]$. Sst expression is detectable prenatally while Pv-expressing interneurons are not detectable until postnatal stages. For specification of MGE-derived interneuron subtypes, the transcription factor Nkx2.1 is required [25]. In mice Nkx2.1 is first expressed at the 1-somite stage in the median aspect of the anterior neural plate. By the time that 11 somites have formed (approximately GD 8.5), this gene is expressed in the ventromedian telencephalon, the region from which the ganglionic eminences arise [83]. Maintenance of Nkx2.1 expression requires both Sonic hedgehog (Shh) [41] and Fgf8 signaling [86].

In addition to interneurons, the ganglionic eminences give rise to oligodendrocytes, cells that form the myelin that insulates axons of the CNS. Oligodendrocytes arise from Nkx2.1expressing progenitor cells that are found in the MGEs, POA, and AEP [50,69,75,80,96]. For the specification and maturation of oligodendrocyte progenitor cells, the expression of Olig2, a Shh-induced basic helix loop helix (bHLH) transcription factor, is required [69].

Previous studies have demonstrated prenatal ethanol exposure-mediated insult to both oligodendrocyte [74] and interneuron populations $[14,29,39,46,65,66]$. In contrast to the current investigation, however, the former studies employed chronic ethanol exposure paradigms. Here we present evidence that ethanol exposure limited to a very narrow window of time prior to neural plate formation variably reduces the tissue of the ventromedian 
forebrain; tissue from which components of the basal ganglia, as well as cortical interneurons and oligodendrocytes arise. The potential consequences of this tissue loss are discussed.

\section{METHODS}

\section{Animal husbandry and treatment paradigm}

C57B1/6J mice (The Jackson Laboratory, Bar Harbor, ME) were maintained on an ad libitum diet of standard laboratory chow and water. Early in the light cycle, 2 females were placed with a single male for a 2 hour period, and then examined for the presence of a copulation plug. The beginning of this breeding period was defined as gestational day (GD) 0 . On their $7^{\text {th }}$ day of pregnancy, mice in the experimental group were administered two doses of $25 \%(\mathrm{v} / \mathrm{v})$ ethanol in lactated Ringer's solution at a dosage of $2.9 \mathrm{~g} / \mathrm{kg}$ maternal body weight by intraperitoneal (i.p.) injection. The injections were given $4 \mathrm{~h}$ apart, with the first administered at GD 7, $0 \mathrm{~h}$, and resulting in maternal peak blood ethanol concentrations averaging $440 \mathrm{mg} / \mathrm{dl}$ (range: $400-466 \mathrm{mg} / \mathrm{dl}$ ) 30 minutes after the second dose [38]. Control animals were injected with an equivalent volume of lactated Ringer's solution according to the above treatment paradigm.

For the studies described herein, on day 12.5, 13, or 17 of pregnancy, dams were anesthetized via $\mathrm{CO}_{2}$ inhalation followed by cervical dislocation. The majority of severely affected ethanol-exposed animals [i.e. those with holoprosencephaly (HPE)] do not survive beyond the first few postnatal days, therefore only prenatal animals were utilized for this study. Following laparotomy, the uteri were removed and the embryos or fetuses were immediately dissected free of decidua in ice-cold phosphate buffered-saline (PBS) and examined for the presence of gross abnormalities. Ethanol-exposed fetuses were selected, based on the degree of ocular and facial dysmorphology, to provide a spectrum of affected animals. For this study, all of the selected ethanol-exposed specimens had ocular defects. Some of these had apparently normal facies, while others had facial features characteristic of FAS (as described in [90]). Control animals were stage-matched to corresponding ethanolexposed animals based on the degree of limb (GD 12.5 and 13), skin and hair follicle (GD 17) development [97]. All animal treatment protocols were approved by the University of North Carolina at Chapel Hill, Institutional Animal Care and Use Committee (IACUC).

\section{Scanning electron microscopy}

GD 13 embryos chosen for scanning electron microscopy were decapitated, dissected and immersion fixed for 48 hours in a $2.5 \%$ gluteraldehyde fixative. Specimens were rinsed in Sorenson's phosphate buffer at which time the lateral wall of both left and right cerebral hemispheres were removed. Embryos were post-fixed in $2 \%$ osmium tetroxide for 1 hour, dehydrated in a graded ethanol series, and critical point dried with $\mathrm{CO}_{2}$. Embryos were then mounted on aluminum stubs and sputter coated with gold palladium. Scanning was performed at $15 \mathrm{kV}$ on a JEOL scanning electron microscope.

\section{Routine histology}

GD 13 embryos were immersed in Bouins fixative (Sigma Aldrich) for a week, and were then rinsed with $70 \%$ ethanol until the residual fixative was no longer evident. Specimens were processed overnight for routine paraffin embedding using a tissue processor. Coronal sections were cut at $8 \mu \mathrm{m}$, mounted on glass slides, stained with aqueous hemotoxylin and eosin (H \& E), cover-slipped and viewed with a light microscope. Photographs of sections were taken using a Nikon photomicroscope. 


\section{In situ hybridization}

For in situ hybridization, GD 12.5 embryos were immersion fixed overnight at $4^{\circ}$ in RNase free $4 \%$ paraformaldehyde. They were then transferred to a $15 \%$ sucrose solution, where they remained for 24 hours prior to freezing in OCT medium and storage at $-80^{\circ}$. Serial cryosections were cut at $20 \mu \mathrm{m}$ and collected on glass slides, followed by storage at $-20^{\circ}$. Following treatment with proteinase $\mathrm{K}$ and triethanolamine, sections were hybridized overnight at $60^{\circ}$ with digoxigenin-labeled riboprobes for either Nkx2.1 or Fzd8 (generated by Yongquin Wu of the In Situ Hybridization Core Facility at UNC). After washing and blocking, the sections were incubated with an anti-digoxigenin alkaline phosphatase (AP) antibody and developed using BM Purple AP Substrate (Roche). After development, the sections were fixed in $4 \%$ paraformaldehyde to quench the AP activity and then were mounted with CC/Mount (Sigma), followed by photography employing a Nikon photomicroscope.

\section{Immunohistochemistry}

For immunohistochemistry, GD 12.5 and 17 specimens were immersion fixed with $4 \%$ paraformaldehyde, processed using a tissue processor and embedded in paraffin. Specimens were sectioned in the coronal plane at $10 \mu \mathrm{m}$, followed by deparaffination, rehydration, and quenching with $\mathrm{H}_{2} \mathrm{O}_{2}$. Steam antigen retrieval was performed in combination with an antigen retrieval citra solution (Biogenex). The following primary antibodies were used: rabbit anti-GABA (1:1000, Sigma-Aldrich), rabbit anti-Olig2 (DF308 at 1:20,000 generously provided by C. Stiles and J. Alberta, Dana Farber Cancer Institute), and rabbit anti-somatostatin (1:500, Millipore). Following incubation with anti-rabbit secondary antibody and avidin/biotin-immunoperoxidase reactions (Vector Laboratories), antigen was detected using diaminobenzidine as a substrate (Innovex Biosciences). Sections from both control and ethanol-exposed animals were stained at the same time to control for any variability in technique. Photographs of sections were taken using a Nikon photomicroscope.

\section{RESULTS}

GD 13 embryos that had been acutely exposed to ethanol on GD 7 were selected for subsequent scanning electron microscopic or histological analyses based on ocular and facial morphology in order to illustrate a range of ethanol-induced teratogenesis. All of the ethanol-exposed animals selected had some degree of ocular abnormality, with defects ranging from slight microphthalmia to apparent anophthalmia. Abnormal facial features, which consisted of a long upper lip, narrow snout with closely apposed nostrils, and small mandible (Fig $1 \mathrm{~d}$, g) were present in only the most severely affected animals examined. Accompanying ethanol-induced facial dysmorphology, in ethanol-exposed embryos from which the lateral aspects of the cerebral cortices were removed, scanning electron microscopy revealed abnormalities involving the hippocampus, which was diminished in size, with reduction being most evident in the rostral aspect (Fig $1 \mathrm{e}, \mathrm{f} ; \mathrm{h}, \mathrm{i}$ ). Additionally, the foramina of Monro were enlarged and the cortical wall thickness appeared reduced in these affected animals.

Ethanol-induced CNS abnormalities can also be appreciated in routine histological sections of GD 13 embryos. Shown in Figure 2 are coronal sections of a control (Fig 2 a,e) and 3 differentially-affected ethanol-exposed animals (Fig 2 b-d, f-h). Two sections made at comparable anterior-posterior levels are shown for each of the four embryos included. The images from the affected embryos are arranged, from left to right, in increasing degrees of severity based on ventromedian forebrain deficiency. In the most mildly affected animal (Fig 2 b,f), a rostral section thorough the cerebral hemispheres illustrates the close proximity of the ventral aspect of the cortex and ganglionic eminences. Further posteriorly, instead of 
the normally distinct bilateral LGE, MGE, and the centrally-located POA, there are only 3 prominent basal forebrain elevations. Additionally, the lateral ventricles and foramina of Monro (arrow in Fig 2e) appear larger than normal, while the hippocampus is slightly reduced in its dorso-ventral dimension. In an animal that was somewhat more severely affected (Figure $2 \mathrm{c}, \mathrm{g}$,) the cerebral hemispheres remain separate dorsally, but are approximated ventrally. Rostrally, the GEs are positioned on the ventromedial aspect of the basal forebrain, as compared to their normal ventrolateral location (Fig 2c). Further posterior, the basal forebrain has 3 major tissue elevations, as in the more mildly affected animal, but the median tissue mass is smaller (Fig $2 \mathrm{~g}$ ). In this specimen, the reduction in the hippocampus is also more pronounced and the foramina of Monro are notably enlarged. In the most severely affected ethanol-exposed animal shown, the cerebral hemispheres are united, as are the lateral ventricles (Fig 2d). The basal forebrain of this specimen is comprised of a single tissue mass both rostrally and caudally (Fig $2 \mathrm{~d}, \mathrm{~h}$ ). In this animal, the hippocampus is significantly reduced and the cortex is notably thin relative to the control (Fig $2 \mathrm{~h}$ ). Examination of sections from each of the ethanol-exposed animals at more caudal levels than shown illustrated a relatively spared mid- and hindbrain (data now shown), confirming previous reports that the ventromedian forebrain shows the most severe gross brain dysmorphology following GD 7 ethanol insult.

In situ hybridization employing region-specific probes was used to more precisely identify tissues affected in embryos following GD 7 ethanol exposure. As illustrated in Figure 3 $(\mathrm{a}, \mathrm{e})$, on GD 12.5 in mice, Nkx2.1 expression is normally localized to the POA and MGEs, while Fzd8 expression is limited to the ventricular zone of the LGEs and the cerebral cortex (as described in [98]). As in the control, in a mildly affected ethanol-exposed embryo, Nkx2.1 heavily labels the POA even though the width of this region is diminished (Fig 3b,f). This median tissue loss is accompanied by abnormally close proximity of the Fzd8-labeled tissue (Fig 3f). The ethanol-exposed animal shown in Figure $3 \mathrm{c}$ and $\mathrm{g}$ is affected to a somewhat greater degree than the animal shown in Figure $2 \mathrm{c}$ and $\mathrm{g}$. In this animal, median union of the Nkx2.1-labeled tissue is apparent. Notably, the ventral midline region remains heavily labeled (arrowhead in Fig 3c). Although the ethanol-induced reduction in the ventromedian forebrain tissues is evident, despite being too closely approximated, the Fzd8labeled LGEs and cortex appear quite normal (Fig 3g). In this animal the hippocampus is much reduced and the foramina of Monro are substantially enlarged. In the most severely affected embryo shown, Nkx2.1 labeling is limited to a median strip, with the normally intense ventromedian staining being notably reduced (Fig 3d). This is accompanied by Fzd8 expression which extends to the midline of the basal forebrain.

To further examine ethanol's effect on the basal forebrain, antibodies for Olig2, a transcription factor necessary for the specification of oligodendrocyte progenitor cells, and for GABA, an inhibitory neurotransmitter, were employed. As shown in sections from a control GD 12.5 embryo, expression of Olig2 is normally restricted to the POA as well as both the MGEs and LGEs, with staining being least intense in the LGEs (Fig 4a). It is primarily localized to the ventricular zone, although some darkly stained cells are also located in the subjacent subventricular zone. At this stage in development, immunohistochemical labeling identifies GABA expression throughout the subventricular and mantle zones of the basal forebrain (Fig 4e). In embryos affected to degrees comparable to those shown in Figure 3, an expected reduction in Olig2 and GABA labeling was found. As shown in Figure 4 (b), a mild degree of affect is evidenced by a reduced POA, along with a deficiency in the POA-associated Olig2 and GABA staining. In severely affected animals (Fig 4c,d; g,h), with loss of much of the MGE area, there is concomitant loss of Olig2 and GABA staining. 
In order to examine some of the later consequences of ethanol-induced ventromedian forebrain deficiency, immunohistochemical staining for somatostatin (Sst)-expressing interneurons was conducted on brain sections from GD 17 fetuses. At this time in development, these cells normally are migrating tangentially from the MGEs to the cerebral cortex. As shown in sections from a control fetus (Fig 5a,c) Sst-expressing cells are evident in the subpallium. Shown in Figure $5 \mathrm{c}$ is a high magnification view that illustrates the normal morphology of these cells. Figures $5 \mathrm{~b}$ and $\mathrm{d}$ show low and high magnification views of a Sst-labeled section from a GD 17 fetus that had been exposed acutely to ethanol on GD 7. In this animal, the size and shape of the basal ganglia appear abnormal, the septal nuclei are not present, and the anterior commissure appears thickened, a finding that is consistent with previous analyses of this animal model $[38,71]$. The Sst-labeled cells are clearly dysmorphic.

\section{DISCUSSION}

While it has long been recognized that acute high dose ethanol exposure at early gastrulation stages in mice selectively impacts the forebrain [82,89,91], there is only one previous study employing this FASD model in which a detailed examination of ethanol-induced insult to specific forebrain populations is reported [82]. In this previous report, a reduction in choline acetyltransferase (ChAT)-expressing neurons in the forebrain of fetal mice following GD 7 ethanol exposure was shown. Within the past fifteen years, the fact that the ventromedian forebrain serves as a source for tangentially-migrating interneurons and oligodendrocytes has been firmly established $[5,61,103]$. More recently, transcription factors that regulate the differentiation of interneurons have been identified, and mechanisms controlling tangential migration have been defined $[12,76]$. This new information is critical for more fully understanding the impact of ethanol-induced ventromedian forebrain deficiency. In the current study, the region or cell type-specific markers, Nkx2.1, Fzd8, Olig2, and GABA, were employed to further examine ethanol's teratogenic effect. Reductions in MGE and POA tissues and effects on oligodendrocyte and GABAergic interneuron progenitor populations have been shown.

The Nkx2.1 and Fzd8 expression pattern alterations identified in this study are remarkably similar to that in the Nkx2.1 mutant mouse described by Sussel and colleagues [93]. This study was the first to show that $\mathrm{Nkx} 2.1$ is required for normal development of the pallidumrelated ventral telencephalon. The mutant mice lacked a morphological and molecular MGE, although the dorsal telencephalon was relatively normal. The globus pallidus (pallidum), a derivative of the MGE, was absent at later stages of development, and instead, was replaced by striatal-like tissue. Also, there was an overall reduction in an isoform of glutamic acid decarboxylase (Gad67), a GABA synthesizing enzyme. Similar to the results of the ethanolteratogenesis studies of Schambra et al [82], cholinergic neurons, another subset of progenitor cells derived from the MGE/POA region, were also absent in the Nkx2.1 mutant [93].

Nkx2.1 expression is dependent on Shh signaling. Shh is a ventralizing morphogen that is necessary for cell proliferation, differentiation, and embryonic patterning. At gastrulation stages, Shh is expressed in the notochord, prechordal plate, and floor plate of the neural tube. In mouse embryos having approximately 8 somites (approximately GD 8.5), its expression can be localized to the median aspect of the anterior neural plate. By about GD 9.5, Shh is expressed in the mantle zone of the MGEs [83]. Importantly, mutations in Shh result in HPE, one of the severe manifestations of early prenatal alcohol exposure [28,79,84,89]. 
Recognizing that early gastrulation stages represent a critical exposure time for FAS and that Shh is a key signaling pathway at this point in time, a number of investigations have explored insult to this pathway as a primary mechanism of ethanol's teratogenesis $[2,8,18,43,55-57,110]$. The results of studies employing a variety of animal models, including zebrafish, chicks, and mice, have provided evidence indicating that ethanol exposure occurring during gastrulation does decrease Shh expression, with resulting craniofacial and CNS abnormalities being consistent with HPE. Strongly supporting a role for diminished Shh signaling is that the ethanol-induced defects can be rescued by Shh [2,56] or by other molecules involved in Shh signaling [i.e. cholesterol [55]]. Despite a considerable amount of work, however, it remains unclear whether the ethanol-mediated affects on Shh signaling are direct or indirect.

The results of the current work highlight the potential of acute, early ethanol insult to have a protracted effect on the structure and function of the developing brain. A reduction in the tissues from which GABAergic populations are derived is expected to have functional consequences that might include disruption in the balance of excitation and inhibition in the CNS. In this regard it is notable that ADHD is the highest comorbidity in FASD [35,42]; an outcome that may, at least in part, result from reduced GABAergic neurotransmission [81,100]. Another result of inhibitory interneuron loss is seizure activity [26]. Importantly, seizures are estimated to occur in $3-21 \%$ of children with FASD

$\left[16,44,45,49,{ }^{59},{ }^{60}, 67,72,73,92\right]$. The developmental basis for this remains unknown, though Bonthius and colleagues $[19,20]$ have suggested that ethanol-induced hippocampal dysfunction may be one cause. Additionally, Godin et al [38] have proposed that seizure activity might be the result of an error in cell migration leading to the development of cerebral cortical heterotopias. Also notable are that seizures are common in patients with HPE [30,95]; a decrease in interneurons in individuals with HPE has been reported [32]; and individuals with Shh mutations that have microcephaly, but lack overt HPE features, present with hyperactivity and seizures. Also, in the Nkx2.1 mutant mouse, there are reduced populations of interneurons [93]. In fact, $\mathrm{Nkx} 2.1$ has been suggested to regulate the balance of excitation and inhibition in the postnatal cerebral cortex [41]. Although the mutant mice do not survive postnatally because of lung and thyroid problems, a conditional knockout of the gene on either GD 9.5 or 10.5 is consistent with viability. These conditional knockouts develop spontaneous seizures as juveniles, a finding thought to be related to decreased GABA activity [25]. Clearly, studies directed toward examining seizure thresholds in the FASD mouse model employed for the current study are needed.

In addition to hyperactivity and seizures, another potential consequence of abnormal GABA levels is altered sensitivity to GABA-modulating drugs, including ethanol. Ethanol is a GABA-agonist, an action that yields relaxing, anti-anxiety effects. That most individuals with FASD have an increased risk for developing both alcohol and drug abuse problems may, in part, be related to their need to drink more in order to achieve a desired effect $[3,4,13,15,31,51,70,87]$. Interestingly, a reduced ataxic and hypothermic response to an acute ethanol challenge has been demonstrated among mice that were exposed to ethanol on GD 7 (personal communication, SOM).

In addition to the consequences of damage to GABAergic populations, additional consideration of early ethanol-mediated insult involving oligodendrocyte populations is warranted. A marked reduction in the tissue from which oligodendrocyte progenitor cell populations originated was shown in this study. Importantly, in human FASD, fiber tracts, including the corpus callosum, are affected. Defects in the corpus callosum have been shown to range from complete agenesis to decreased white matter organization/integrity $\left[10,11,17,21-23,36,48,52 \_54,58,78,85,94,105,106\right]$. While the existence of functionally redundant oligodendrocyte progenitor cells that may compensate if another population is 
affected has been suggested $[47,50,64]$, it remains possible that loss of ventromedian derived-oligodendrocyte progenitor cells may contribute to the white matter integrity changes that follow prenatal ethanol exposure. Additional investigations directed toward examining early ethanol exposure mediated effects on myelination in later prenatal and postnatal stages are indicated.

Imaging studies assessing human FASD have shown that individuals prenatally exposed to ethanol have basal ganglia that are reduced in size $[9,10,27,62]$. Importantly, Sowell and colleagues have recently identified size reductions in the pallidum that are associated with the upper median facial dysmorphology that characterizes FAS (personal communication). This result is consistent with an early insult comparable to that in the model employed for this study. In the mice, it would be of interest to explore ethanol-induced functional changes in movement as might be expected to follow insult to the pallidum [40].

In conclusion, the results of this study show that in mice, acute ethanol exposure occurring at a time in development equivalent to that in the third week of pregnancy in humans adversely affects the ventromedian forebrain, reducing tissues that are a source of interneuron and oligodendrocyte populations and that form the septal region and components of basal ganglia, especially the pallidum. The functional consequences of this insult are expected to include an increased potential for hyperactivity, seizures and susceptibility to drug and alcohol abuse. This work highlights the need for additional preand postnatal studies directed toward a more comprehensive examination of ethanol-induced ventromedian forebrain deficiency and resulting structural and functional changes.

\section{Acknowledgments}

Sources of support: This work was supported by NIH/NIAAA grants AA007573, AA011605, AA017124; and was conducted in conjunction with the Collaborative Initiative on Fetal Alcohol Spectrum Disorders (CIFASD). Additional information about CIFASD can be found at www.cifasd.org.

\section{References}

1. Abel EL, Sokol RJ. Fetal alcohol syndrome is now leading cause of mental retardation. Lancet. 1986; 2:1222. [PubMed: 2877359]

2. Ahlgren SC, Thakur V, Bronner-Fraser M. Sonic hedgehog rescues cranial neural crest from cell death induced by ethanol exposure. Proc Natl Acad Sci U S A. 2002; 99:10476-81. [PubMed: 12140368]

3. Alati R, Al Mamun A, Williams GM, O'Callaghan M, Najman JM, Bor W. In utero alcohol exposure and prediction of alcohol disorders in early adulthood: a birth cohort study. Arch Gen Psychiatry. 2006; 63:1009-16. [PubMed: 16953003]

4. Alati R, Clavarino A, Najman JM, O'Callaghan M, Bor W, Mamun AA, Williams GM. The developmental origin of adolescent alcohol use: findings from the Mater University Study of Pregnancy and its outcomes. Drug Alcohol Depend. 2008; 98:136-43. [PubMed: 18639392]

5. Anderson SA, Eisenstat DD, Shi L, Rubenstein JL. Interneuron migration from basal forebrain to neocortex: dependence on Dlx genes. Science. 1997; 278:474-6. [PubMed: 9334308]

6. Anderson SA, Kaznowski CE, Horn C, Rubenstein JL, McConnell SK. Distinct origins of neocortical projection neurons and interneurons in vivo. Cereb Cortex. 2002; 12:702-9. [PubMed: 12050082]

7. Anderson SA, Marin O, Horn C, Jennings K, Rubenstein JL. Distinct cortical migrations from the medial and lateral ganglionic eminences. Development. 2001; 128:353-63. [PubMed: 11152634]

8. Aoto K, Shikata Y, Higashiyama D, Shiota K, Motoyama J. Fetal ethanol exposure activates protein kinase A and impairs Shh expression in prechordal mesendoderm cells in the pathogenesis of holoprosencephaly. Birth Defects Res A Clin Mol Teratol. 2008; 82:224-31. [PubMed: 18338389] 
9. Archibald SL, Fennema-Notestine C, Gamst A, Riley EP, Mattson SN, Jernigan TL. Brain dysmorphology in individuals with severe prenatal alcohol exposure. Dev Med Child Neurol. 2001; 43:148-54. [PubMed: 11263683]

10. Astley SJ, Aylward EH, Olson HC, Kerns K, Brooks A, Coggins TE, Davies J, Dorn S, Gendler B, Jirikowic T. Magnetic resonance imaging outcomes from a comprehensive magnetic resonance study of children with fetal alcohol spectrum disorders. Alcohol Clin Exp Res. 2009; 33:1671-89. others. [PubMed: 19572986]

11. Autti-Ramo I, Autti T, Korkman M, Kettunen S, Salonen O, Valanne L. MRI findings in children with school problems who had been exposed prenatally to alcohol. Dev Med Child Neurol. 2002; 44:98-106. [PubMed: 11848116]

12. Ayala R, Shu T, Tsai LH. Trekking across the brain: the journey of neuronal migration. Cell. 2007; 128:29-43. [PubMed: 17218253]

13. Baer JS, Sampson PD, Barr HM, Connor PD, Streissguth AP. A 21-year longitudinal analysis of the effects of prenatal alcohol exposure on young adult drinking. Arch Gen Psychiatry. 2003; 60:377-85. [PubMed: 12695315]

14. Bailey CD, Brien JF, Reynolds JN. Chronic prenatal ethanol exposure alters the proportion of GABAergic neurons in layers II/III of the adult guinea pig somatosensory cortex. Neurotoxicol Teratol. 2004; 26:59-63. [PubMed: 15001214]

15. Barr HM, Bookstein FL, O'Malley KD, Connor PD, Huggins JE, Streissguth AP. Binge drinking during pregnancy as a predictor of psychiatric disorders on the Structured Clinical Interview for DSM-IV in young adult offspring. Am J Psychiatry. 2006; 163:1061-5. [PubMed: 16741207]

16. Bell SH, Stade B, Reynolds JN, Rasmussen C, Andrew G, Hwang PA, Carlen PL. The Remarkably High Prevalence of Epilepsy and Seizure History in Fetal Alcohol Spectrum Disorders. Alcohol Clin Exp Res. 2010

17. Bhatara VS, Lovrein F, Kirkeby J, Swayze V 2nd, Unruh E, Johnson V. Brain function in fetal alcohol syndrome assessed by single photon emission computed tomography. S D J Med. 2002; 55:59-62. [PubMed: 11865707]

18. Blader P, Strahle U. Ethanol impairs migration of the prechordal plate in the zebrafish embryo. Dev Biol. 1998; 201:185-201. [PubMed: 9740658]

19. Bonthius DJ, Pantazis NJ, Karacay B, Bonthius NE, Taggard, Da, Lothman EW. Alcohol exposure during the brain growth spurt promotes hippocampal seizures, rapid kindling, and spreading depression. Alcohol Clin Exp Res. 2001; 25:734-45. [PubMed: 11371723]

20. Bonthius DJ, Woodhouse J, Bonthius NE, Taggard DA, Lothman EW. Reduced seizure threshold and hippocampal cell loss in rats exposed to alcohol during the brain growth spurt. Alcohol Clin Exp Res. 2001; 25:70-82. [PubMed: 11198717]

21. Bookstein FL, Connor PD, Huggins JE, Barr HM, Pimentel KD, Streissguth AP. Many infants prenatally exposed to high levels of alcohol show one particular anomaly of the corpus callosum. Alcohol Clin Exp Res. 2007; 31:868-79. [PubMed: 17386071]

22. Bookstein FL, Sampson PD, Connor PD, Streissguth AP. Midline corpus callosum is a neuroanatomical focus of fetal alcohol damage. Anat Rec. 2002; 269:162-74. [PubMed: 12124903]

23. Bookstein FL, Streissguth AP, Sampson PD, Connor PD, Barr HM. Corpus callosum shape and neuropsychological deficits in adult males with heavy fetal alcohol exposure. Neuroimage. 2002; 15:233-51. [PubMed: 11771992]

24. Butt SJ, Cobos I, Golden J, Kessaris N, Pachnis V, Anderson S. Transcriptional regulation of cortical interneuron development. J Neurosci. 2007; 27:11847-50. [PubMed: 17978022]

25. Butt SJ, Sousa VH, Fuccillo MV, Hjerling-Leffler J, Miyoshi G, Kimura S, Fishell G. The requirement of Nkx2-1 in the temporal specification of cortical interneuron subtypes. Neuron. 2008; 59:722-32. [PubMed: 18786356]

26. Cobos I, Calcagnotto ME, Vilaythong AJ, Thwin MT, Noebels JL, Baraban SC, Rubenstein JL. Mice lacking Dlx1 show subtype-specific loss of interneurons, reduced inhibition and epilepsy. Nat Neurosci. 2005; 8:1059-68. [PubMed: 16007083] 
27. Cortese BM, Moore GJ, Bailey BA, Jacobson SW, Delaney-Black V, Hannigan JH. Magnetic resonance and spectroscopic imaging in prenatal alcohol-exposed children: preliminary findings in the caudate nucleus. Neurotoxicol Teratol. 2006; 28:597-606. [PubMed: 16996247]

28. Coulter CL, Leech RW, Schaefer GB, Scheithauer BW, Brumback RA. Midline cerebral dysgenesis, dysfunction of the hypothalamic-pituitary axis, and fetal alcohol effects. Arch Neurol. 1993; 50:771-5. [PubMed: 8323485]

29. Cuzon VC, Yeh PW, Yanagawa Y, Obata K, Yeh HH. Ethanol consumption during early pregnancy alters the disposition of tangentially migrating GABAergic interneurons in the fetal cortex. J Neurosci. 2008; 28:1854-64. [PubMed: 18287502]

30. Demyer W, White PT. Eeg in Holoprosencephaly (Arhinencephaly). Arch Neurol. 1964; 11:50720. [PubMed: 14200659]

31. Famy C, Streissguth AP, Unis AS. Mental illness in adults with fetal alcohol syndrome or fetal alcohol effects. Am J Psychiatry. 1998; 155:552-4. [PubMed: 9546004]

32. Fertuzinhos S, Krsnik Z, Kawasawa YI, Rasin MR, Kwan KY, Chen JG, Judas M, Hayashi M, Sestan N. Selective depletion of molecularly defined cortical interneurons in human holoprosencephaly with severe striatal hypoplasia. Cereb Cortex. 2009; 19:2196-207. [PubMed: 19234067]

33. Flames N, Pla R, Gelman DM, Rubenstein JL, Puelles L, Marin O. Delineation of multiple subpallial progenitor domains by the combinatorial expression of transcriptional codes. J Neurosci. 2007; 27:9682-95. [PubMed: 17804629]

34. Fogarty M, Grist M, Gelman D, Marin O, Pachnis V, Kessaris N. Spatial genetic patterning of the embryonic neuroepithelium generates GABAergic interneuron diversity in the adult cortex. $\mathrm{J}$ Neurosci. 2007; 27:10935-46. [PubMed: 17928435]

35. Fryer SL, McGee CL, Matt GE, Riley EP, Mattson SN. Evaluation of psychopathological conditions in children with heavy prenatal alcohol exposure. Pediatrics. 2007; 119:e733-41. [PubMed: 17332190]

36. Fryer SL, Schweinsburg BC, Bjorkquist OA, Frank LR, Mattson SN, Spadoni AD, Riley EP. Characterization of white matter microstructure in fetal alcohol spectrum disorders. Alcohol Clin Exp Res. 2009; 33:514-21. [PubMed: 19120066]

37. Gelman DM, Martini FJ, Nobrega-Pereira S, Pierani A, Kessaris N, Marin O. The embryonic preoptic area is a novel source of cortical GABAergic interneurons. J Neurosci. 2009; 29:9380-9. [PubMed: 19625528]

38. Godin EA, O'Leary-Moore SK, Khan AA, Parnell SE, Ament JJ, Dehart DB, Johnson BW, Allan Johnson G, Styner MA, Sulik KK. Magnetic resonance microscopy defines ethanol-induced brain abnormalities in prenatal mice: effects of acute insult on gestational day 7. Alcohol Clin Exp Res. 2010; 34:98-111. [PubMed: 19860813]

39. Granato A. Altered organization of cortical interneurons in rats exposed to ethanol during neonatal life. Brain Res. 2006; 1069:23-30. [PubMed: 16386714]

40. Grillner S, Hellgren J, Menard A, Saitoh K, Wikstrom MA. Mechanisms for selection of basic motor programs--roles for the striatum and pallidum. Trends Neurosci. 2005; 28:364-70. [PubMed: 15935487]

41. Gulacsi A, Anderson SA. Shh maintains Nkx2.1 in the MGE by a Gli3-independent mechanism. Cereb Cortex. 2006; 16(Suppl 1):i89-95. [PubMed: 16766713]

42. Herman LE, Acosta MC, Chang PN. Gender and attention deficits in children diagnosed with a Fetal Alcohol Spectrum Disorder. Can J Clin Pharmacol. 2008; 15:e411-9. [PubMed: 18953085]

43. Higashiyama D, Saitsu H, Komada M, Takigawa T, Ishibashi M, Shiota K. Sequential developmental changes in holoprosencephalic mouse embryos exposed to ethanol during the gastrulation period. Birth Defects Res A Clin Mol Teratol. 2007; 79:513-23. [PubMed: 17393481]

44. Ioffe S, Chernick V. Prediction of subsequent motor and mental retardation in newborn infants exposed to alcohol in utero by computerized EEG analysis. Neuropediatrics. 1990; 21:11-7. [PubMed: 2314553]

45. Iosub S, Fuchs M, Bingol N, Gromisch DS. Fetal alcohol syndrome revisited. Pediatrics. 1981; 68:475-9. [PubMed: 7198771] 
46. Isayama RN, Leite PE, Lima JP, Uziel D, Yamasaki EN. Impact of ethanol on the developing GABAergic system. Anat Rec (Hoboken). 2009; 292:1922-39. [PubMed: 19943346]

47. Ivanova A, Nakahira E, Kagawa T, Oba A, Wada T, Takebayashi H, Spassky N, Levine J, Zalc B, Ikenaka K. Evidence for a second wave of oligodendrogenesis in the postnatal cerebral cortex of the mouse. J Neurosci Res. 2003; 73:581-92. [PubMed: 12929126]

48. Johnson VP, Swayze VW II, Sato Y, Andreasen NC. Fetal alcohol syndrome: craniofacial and central nervous system manifestations. Am J Med Genet. 1996; 61:329-39. [PubMed: 8834044]

49. Jones KL, Smith DW. The fetal alcohol syndrome. Teratology. 1975; 12:1-10. [PubMed: 1162620]

50. Kessaris N, Fogarty M, Iannarelli P, Grist M, Wegner M, Richardson WD. Competing waves of oligodendrocytes in the forebrain and postnatal elimination of an embryonic lineage. Nat Neurosci. 2006; 9:173-9. [PubMed: 16388308]

51. Kodituwakku PW. Defining the behavioral phenotype in children with fetal alcohol spectrum disorders: a review. Neurosci Biobehav Rev. 2007; 31:192-201. [PubMed: 16930704]

52. Lebel C, Rasmussen C, Wyper K, Andrew G, Beaulieu C. Brain microstructure is related to math ability in children with fetal alcohol spectrum disorder. Alcohol Clin Exp Res. 34:354-63. [PubMed: 19930234]

53. Lebel C, Rasmussen C, Wyper K, Walker L, Andrew G, Yager J, Beaulieu C. Brain diffusion abnormalities in children with fetal alcohol spectrum disorder. Alcohol Clin Exp Res. 2008; 32:1732-40. [PubMed: 18671811]

54. Li L, Coles CD, Lynch ME, Hu X. Voxelwise and skeleton-based region of interest analysis of fetal alcohol syndrome and fetal alcohol spectrum disorders in young adults. Hum Brain Mapp. 2009; 30:3265-74. [PubMed: 19278010]

55. Li YX, Yang HT, Zdanowicz M, Sicklick JK, Qi Y, Camp TJ, Diehl AM. Fetal alcohol exposure impairs Hedgehog cholesterol modification and signaling. Lab Invest. 2007; 87:231-40. [PubMed: 17237799]

56. Loucks EJ, Ahlgren SC. Deciphering the role of Shh signaling in axial defects produced by ethanol exposure. Birth Defects Res A Clin Mol Teratol. 2009; 85:556-67. [PubMed: 19235835]

57. Loucks EJ, Schwend T, Ahlgren SC. Molecular changes associated with teratogen-induced cyclopia. Birth Defects Res A Clin Mol Teratol. 2007; 79:642-51. [PubMed: 17647295]

58. Ma X, Coles CD, Lynch ME, Laconte SM, Zurkiya O, Wang D, Hu X. Evaluation of corpus callosum anisotropy in young adults with fetal alcohol syndrome according to diffusion tensor imaging. Alcohol Clin Exp Res. 2005; 29:1214-22. [PubMed: 16046877]

59. Majewski F. Alcohol embryopathy: some facts and speculations about pathogenesis. Neurobehav Toxicol Teratol. 1981; 3:129-44. [PubMed: 7195989]

60. Marcus JC. Neurological findings in the fetal alcohol syndrome. Neuropediatrics. 1987; 18:15860. [PubMed: 3683756]

61. Marin O, Rubenstein JL. A long, remarkable journey: tangential migration in the telencephalon. Nat Rev Neurosci. 2001; 2:780-90. [PubMed: 11715055]

62. Mattson SN, Riley EP, Sowell ER, Jernigan TL, Sobel DF, Jones KL. A decrease in the size of the basal ganglia in children with fetal alcohol syndrome. Alcohol Clin Exp Res. 1996; 20:1088-93. [PubMed: 8892532]

63. Menezes JR, Smith CM, Nelson KC, Luskin MB. The division of neuronal progenitor cells during migration in the neonatal mammalian forebrain. Mol Cell Neurosci. 1995; 6:496-508. [PubMed: 8742267]

64. Menn B, Garcia-Verdugo JM, Gonzalez-Perez C. Yaschine, O. Alvarez-Buylla D. Rowitch, A. Origin of oligodendrocytes in the subventricular zone of the adult brain. J Neurosci. 2006; 26:7907-18. [PubMed: 16870736]

65. Moore DB, Quintero MA, Ruygrok AC, Walker DW, Heaton MB. Prenatal ethanol exposure reduces parvalbumin-immunoreactive GABAergic neuronal number in the adult rat cingulate cortex. Neurosci Lett. 1998; 249:25-8. [PubMed: 9672380]

66. Moore DB, Ruygrok AC, Walker DW, Heaton MB. Effects of prenatal ethanol exposure on parvalbumin-expressing GABAergic neurons in the adult rat medial septum. Alcohol Clin Exp Res. 1997; 21:849-56. [PubMed: 9267534] 
67. Murray-Lyon IM. Alcohol and foetal damage. Alcohol Alcohol. 1985; 20:185-8. [PubMed: 4052154]

68. Nery S, Fishell G, Corbin JG. The caudal ganglionic eminence is a source of distinct cortical and subcortical cell populations. Nat Neurosci. 2002; 5:1279-87. [PubMed: 12411960]

69. Nery S, Wichterle H, Fishell G. Sonic hedgehog contributes to oligodendrocyte specification in the mammalian forebrain. Development. 2001; 128:527-40. [PubMed: 11171336]

70. O'Connor MJ, Paley B. Psychiatric conditions associated with prenatal alcohol exposure. Dev Disabil Res Rev. 2009; 15:225-34. [PubMed: 19731386]

71. O'Leary-Moore SK, Godin EA, Jiang Y, Styner MA, Budin F, Parnell SE, Dehart DB, Johnson GA, Oguz I, Sulik KK. Diffusion tensor imaging and tractography define a spectrum of fiber tract dysmorphology in the brains of prenatal ethanol-exposed mice. in prep.

72. O'Malley KD, Barr H. Fetal alcohol syndrome and seizure disorder. Can J Psychiatry. 1998; 43:1051. [PubMed: 9868573]

73. Olegard R, Sabel KG, Aronsson M, Sandin B, Johansson PR, Carlsson C, Kyllerman M, Iversen K, Hrbek A. Effects on the child of alcohol abuse during pregnancy. Retrospective and prospective studies. Acta Paediatr Scand Suppl. 1979; 275:112-21. [PubMed: 291283]

74. Ozer E, Sarioglu S, Gure A. Effects of prenatal ethanol exposure on neuronal migration, neuronogenesis and brain myelination in the mice brain. Clin Neuropathol. 2000; 19:21-5. [PubMed: 10774947]

75. Parras CM, Hunt C, Sugimori M, Nakafuku M, Rowitch D, Guillemot F. The proneural gene Mash1 specifies an early population of telencephalic oligodendrocytes. J Neurosci. 2007; 27:4233-42. [PubMed: 17442807]

76. Polleux F, Whitford KL, Dijkhuizen PA, Vitalis T, Ghosh A. Control of cortical interneuron migration by neurotrophins and PI3-kinase signaling. Development. 2002; 129:3147-60. [PubMed: 12070090]

77. Puelles L, Kuwana E, Puelles E, Bulfone A, Shimamura K, Keleher J, Smiga S, Rubenstein JL. Pallial and subpallial derivatives in the embryonic chick and mouse telencephalon, traced by the expression of the genes Dlx-2, Emx-1, Nkx-2.1, Pax-6, and Tbr-1. J Comp Neurol. 2000; 424:409-38. [PubMed: 10906711]

78. Riley EP, Mattson SN, Sowell ER, Jernigan TL, Sobel DF, Jones KL. Abnormalities of the corpus callosum in children prenatally exposed to alcohol. Alcohol Clin Exp Res. 1995; 19:1198-202. [PubMed: 8561290]

79. Ronen GM, Andrews WL. Holoprosencephaly as a possible embryonic alcohol effect. Am J Med Genet. 1991; 40:151-4. [PubMed: 1897567]

80. Rowitch DH. Glial specification in the vertebrate neural tube. Nat Rev Neurosci. 2004; 5:409-19. [PubMed: 15100723]

81. Sagvolden T, Johansen EB, Aase H, Russell VA. A dynamic developmental theory of attentiondeficit/hyperactivity disorder (ADHD) predominantly hyperactive/impulsive and combined subtypes. Behav Brain Sci. 2005; 28:397-419. discussion 419-68. [PubMed: 16209748]

82. Schambra UB, Lauder JM, Petrusz P, Sulik KK. Development of neurotransmitter systems in the mouse embryo following acute ethanol exposure: a histological and immunocytochemical study. Int J Dev Neurosci. 1990; 8:507-22. [PubMed: 1980786]

83. Shimamura K, Hartigan DJ, Martinez S, Puelles L, Rubenstein JL. Longitudinal organization of the anterior neural plate and neural tube. Development. 1995; 121:3923-33. [PubMed: 8575293]

84. Siebert JR, Astley SJ, Clarren SK. Holoprosencephaly in a fetal macaque (Macaca nemestrina) following weekly exposure to ethanol. Teratology. 1991; 44:29-36. [PubMed: 1957260]

85. Sowell ER, Mattson SN, Kan E, Thompson PM, Riley EP, Toga AW. Abnormal cortical thickness and brain-behavior correlation patterns in individuals with heavy prenatal alcohol exposure. Cereb Cortex. 2008; 18:136-44. [PubMed: 17443018]

86. Storm EE, Garel S, Borello U, Hebert JM, Martinez S, McConnell SK, Martin GR, Rubenstein JL. Dose-dependent functions of Fgf8 in regulating telencephalic patterning centers. Development. 2006; 133:1831-44. [PubMed: 16613831] 
87. Streissguth AP, Bookstein FL, Barr HM, Sampson PD, O'Malley K, Young JK. Risk factors for adverse life outcomes in fetal alcohol syndrome and fetal alcohol effects. J Dev Behav Pediatr. 2004; 25:228-38. [PubMed: 15308923]

88. Sulik KK. Genesis of alcohol-induced craniofacial dysmorphism. Exp Biol Med (Maywood). 2005; 230:366-75. [PubMed: 15956766]

89. Sulik KK, Johnston MC. Embryonic origin of holoprosencephaly: interrelationship of the developing brain and face. Scan Electron Microsc. 1982:309-22. [PubMed: 7167750]

90. Sulik KK, Johnston MC, Webb MA. Fetal alcohol syndrome: embryogenesis in a mouse model. Science. 1981; 214:936-8. [PubMed: 6795717]

91. Sulik KK, Lauder JM, Dehart DB. Brain Malformations in Prenatal Mice Following Acute Maternal Ethanol Administration. Int J Dev Neurosci. 1984; 2:203-214.

92. Sun Y, Strandberg-Larsen K, Vestergaard M, Christensen J, Nybo Andersen AM, Gronbaek M, Olsen J. Binge drinking during pregnancy and risk of seizures in childhood: a study based on the Danish National Birth Cohort. Am J Epidemiol. 2009; 169:313-22. [PubMed: 19064645]

93. Sussel L, Marin O, Kimura S, Rubenstein JL. Loss of Nkx2.1 homeobox gene function results in a ventral to dorsal molecular respecification within the basal telencephalon: evidence for a transformation of the pallidum into the striatum. Development. 1999; 126:3359-70. [PubMed: 10393115]

94. Swayze VW 2nd, Johnson VP, Hanson JW, Piven J, Sato Y, Giedd JN, Mosnik D, Andreasen NC. Magnetic resonance imaging of brain anomalies in fetal alcohol syndrome. Pediatrics. 1997; 99:232-40. [PubMed: 9024452]

95. Takahashi S, Takahashi Y, Kondo N, Orii T. Epileptic seizures and structural abnormalities in a patient with holoprosencephaly. Brain Dev. 2001; 23:264-8. [PubMed: 11377010]

96. Tekki-Kessaris N, Woodruff R, Hall AC, Gaffield W, Kimura S, Stiles CD, Rowitch DH, Richardson WD. Hedgehog-dependent oligodendrocyte lineage specification in the telencephalon. Development. 2001; 128:2545-54. [PubMed: 11493571]

97. Theiler, K. The House Mouse: Atlas of Embryonic Development. Editoin Edition. SpringerVerlag; New York: 1989.

98. Tucker ES, Segall S, Gopalakrishna D, Wu Y, Vernon M, Polleux F, Lamantia AS. Molecular specification and patterning of progenitor cells in the lateral and medial ganglionic eminences. $\mathrm{J}$ Neurosci. 2008; 28:9504-18. [PubMed: 18799682]

99. Valcanis H, Tan SS. Layer specification of transplanted interneurons in developing mouse neocortex. J Neurosci. 2003; 23:5113-22. [PubMed: 12832535]

100. Viggiano D, Grammatikopoulos G, Sadile AG. A morphometric evidence for a hyperfunctioning mesolimbic system in an animal model of ADHD. Behav Brain Res. 2002; 130:181-9. [PubMed: 11864733]

101. Wichterle H, Garcia-Verdugo JM, Herrera DG, Alvarez-Buylla A. Young neurons from medial ganglionic eminence disperse in adult and embryonic brain. Nat Neurosci. 1999; 2:461-6. [PubMed: 10321251]

102. Wichterle H, Turnbull DH, Nery S, Fishell G, Alvarez-Buylla A. In utero fate mapping reveals distinct migratory pathways and fates of neurons born in the mammalian basal forebrain. Development. 2001; 128:3759-71. [PubMed: 11585802]

103. Wonders CP, Anderson SA. The origin and specification of cortical interneurons. Nat Rev Neurosci. 2006; 7:687-96. [PubMed: 16883309]

104. Wonders CP, Taylor L, Welagen J, Mbata IC, Xiang JZ, Anderson SA. A spatial bias for the origins of interneuron subgroups within the medial ganglionic eminence. Dev Biol. 2008; 314:127-36. [PubMed: 18155689]

105. Wozniak JR, Mueller BA, Chang PN, Muetzel RL, Caros L, Lim KO. Diffusion tensor imaging in children with fetal alcohol spectrum disorders. Alcohol Clin Exp Res. 2006; 30:1799-806. [PubMed: 17010147]

106. Wozniak JR, Muetzel RL, Mueller BA, McGee CL, Freerks MA, Ward EE, Nelson ML, Chang PN, Lim KO. Microstructural corpus callosum anomalies in children with prenatal alcohol exposure: an extension of previous diffusion tensor imaging findings. Alcohol Clin Exp Res. 2009; 33:1825-35. [PubMed: 19645729] 
107. Xu Q, Cobos I, De La Cruz E, Rubenstein JL, Anderson SA. Origins of cortical interneuron subtypes. J Neurosci. 2004; 24:2612-22. [PubMed: 15028753]

108. Xu Q, de la Cruz E, Anderson SA. Cortical interneuron fate determination: diverse sources for distinct subtypes? Cereb Cortex. 2003; 13:670-6. [PubMed: 12764043]

109. Xu Q, Guo L, Moore H, Waclaw RR, Campbell K, Anderson SA. Sonic hedgehog signaling confers ventral telencephalic progenitors with distinct cortical interneuron fates. Neuron. 65:32840. [PubMed: 20159447]

110. Yamada Y, Nagase T, Nagase M, Koshima I. Gene expression changes of sonic hedgehog signaling cascade in a mouse embryonic model of fetal alcohol syndrome. J Craniofac Surg. 2005; 16:1055-61. discussion 1062-3. [PubMed: 16327553] 


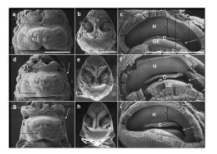

Figure 1.

Scanning electron microscopic analyses of control (a,b,c) and two ethanol-exposed GD 13 embryos (d-i) illustrate that abnormal facial features accompany deficiencies of the forebrain. The facial defects correspond to those in fetal alcohol syndrome and include an indistinct philtrum and long upper lip (black arrows in $\mathrm{d}$ and g), small eyes (white arrows in $\mathrm{d}$ and g), small nose and decreased head circumference. Removal of both left and right lateral walls of the cerebral hemispheres allowed a view of the medial walls and ganglionic eminences (GE) of the forebrain (b,c,e,f,h,i). Obvious abnormalities seen in views of the right side of the control (c) and affected (f and i) forebrains include an enlarged foramen of Monro (arrows in $\mathrm{f}$ and $\mathrm{i}$ ) and reduction in the dorso-ventral dimension of the hippocampus ( $\mathrm{H}$; compare $\{$ in $\mathrm{c}$ and $\mathrm{i}$ ). Additionally, the thickness of the cerebral cortex appeared reduced (double-headed arrows in $\mathrm{c}, \mathrm{f}, \mathrm{i}$ ). $\mathrm{C}=$ choroid plexus. Lines in $\mathrm{c}$ indicate level of sections for Figure 2. Bars in a $-\mathrm{c}=1 \mathrm{~mm}$ 


\section{0.}

Figure 2.

Routine H\&E-stained histological sections of a control (a, e) and 3 ethanol-exposed (b-d, fh) GD 13 embryos illustrate a spectrum of forebrain abnormality. Two coronal sections from each animal are shown, made at the level of the two lines in Figure $1 \mathrm{c}$, with the most anterior ( $\mathrm{a}-\mathrm{d}$ ) being near the level at which the ganglionic eminences are first evident and the more posterior section being at the level of the foramen of Monro (arrow in e-h). In the ethanol-exposed embryos, notable are close apposition of the ganglionic eminences in both the anterior (arrowhead in b, c) and posterior sections (asterisks in $\mathrm{f}, \mathrm{g}$ ). Accompanying this are cerebral cortices that are too close in proximity (indicated by the arrow in a and b), enlarged lateral ventricles and an expanded foramen of Monro (arrow in e-h). Additionally, the rostral aspect of the hippocampus is reduced in its dorso-ventral dimension ( $\{$ in $e-h)$ in the affected specimens and the cerebral cortex is thin (compare line in h to line in e). In the ethanol-exposed animal shown in $\mathrm{d}$ and $\mathrm{h}$, rostrally the lateral ventricles are merged and the brain is holoprosencephalic (d). LV = lateral ventricles, $\mathrm{LGE}=$ lateral ganglionic eminence, $\mathrm{MGE}=$ medial ganglionic eminence, $\mathrm{POA}=$ preoptic area Bar in $\mathrm{a}=1 \mathrm{~mm}$ 


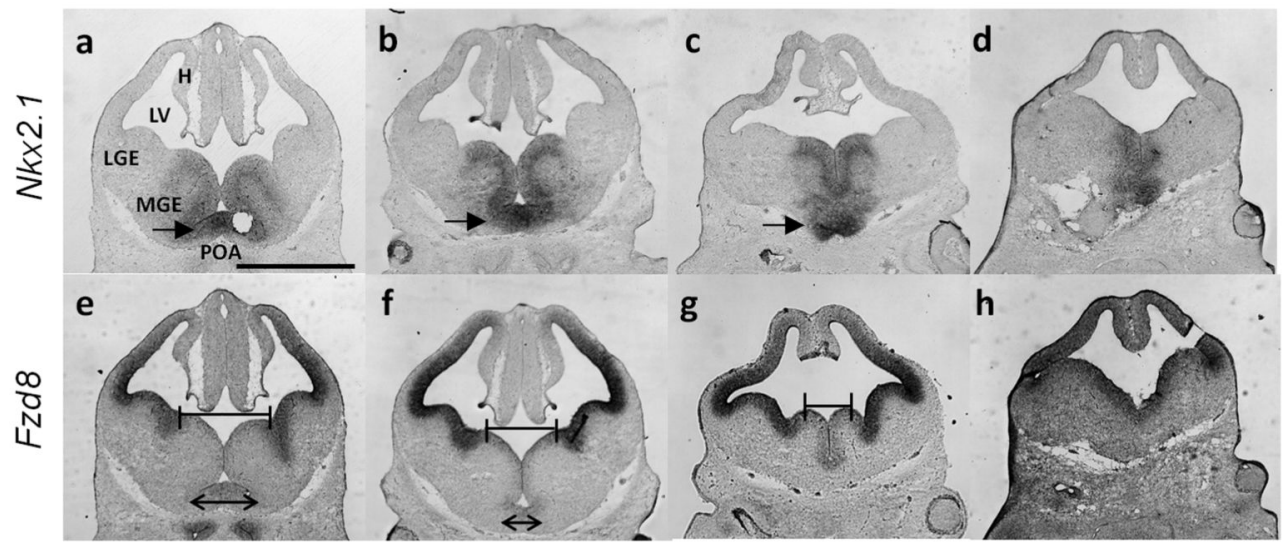

Figure 3.

In situ hybridization, to label $\mathrm{Nkx} 2.1$ and Fzd8 expression in control (a, e) and ethanolexposed (b-d; f-h) GD 12.5 embryos, illustrates median forebrain deficiency involving the POA and MGEs. As shown in the control animal (a), these regions express Nkx2.1. In ethanol-exposed mice, ordered in increasing severity, from left to right, the Nkx2.1-labeled tissue can be seen to diminish accordingly (b-d). In the most mildly affected embryo, the densely stained POA (arrow in a-c) is reduced in width (doublesided arrow in e \& $\mathrm{f}$ ), and in the most severely affected embryo $(\mathrm{d}, \mathrm{h})$, it is absent. Cells of the ventricular zone of the LGE and cortex are labeled with Fzd8, as shown in the control (e). In the ethanol-exposed animals (f-h) Fzd8 expression appears to be relatively unchanged in the LGE and cortical areas. With increasing severity of insult, the distance between the LGEs is reduced (bracket in e-g) to the point where Fzd8 expression surrounds the entire ventricle (h). $\mathrm{H}=$ hippocampus, $\mathrm{LV}=$ lateral ventricles, $\mathrm{LGE}=$ lateral ganglionic eminence, $\mathrm{MGE}=$ medial ganglionic eminence, $\mathrm{POA}=$ preoptic area. $\mathrm{Bar}$ in $\mathrm{a}=1 \mathrm{~mm}$ 

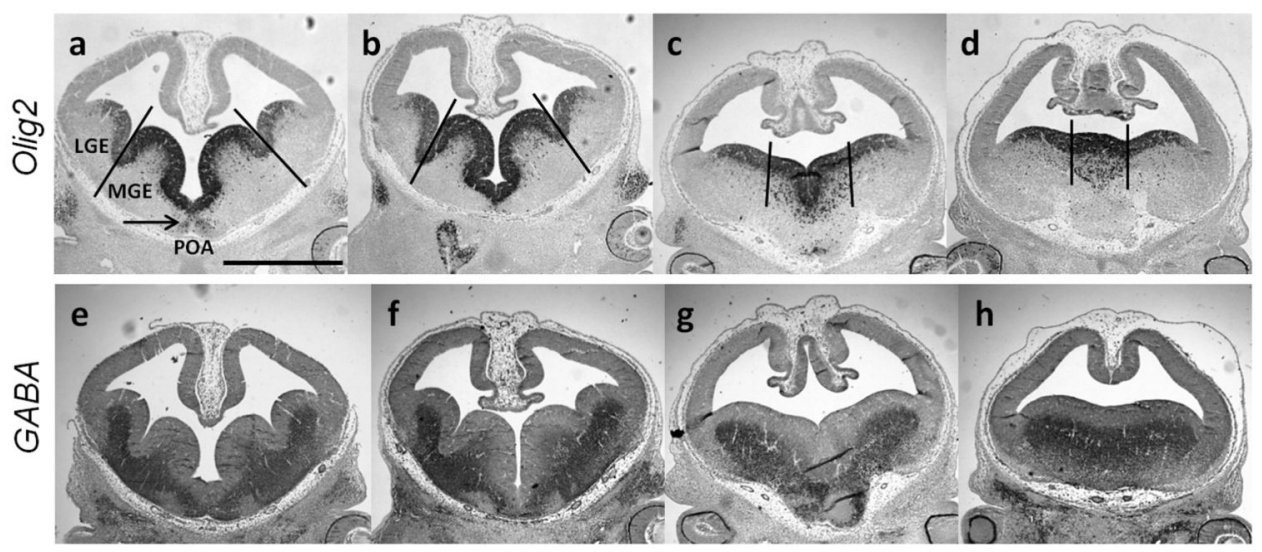

Figure 4.

Immunohistochemical labeling of Olig2 and GABA illustrates deficiency of these basal forebrain markers in ethanol-exposed GD12.5 mice (b-d, f-h) in comparison to a control (a, e). Olig2 (a-d), which is necessary for the specification of oligodendrocyte progenitor cells, is strongly expressed in the ventricular zone of the POA and MGEs (the region between the lines in a), and is more weakly expressed in the LGEs. Patches of cells within the MGE and POA subventricular zone are also Olig2 positive. Accompanying the loss of median tissue, Olig2 expression is reduced in the ethanol-exposed animals (note the region between the lines in b-d). Normally, as shown in the control section in (e), expression of the neurotransmitter GABA is restricted to the subventricular and mantle zones of the basal telencephalon on GD 12.5 in mice. In sections from the same three ethanol-exposed embryos as labeled for Olig2, GABA expression is reduced in accord with the ethanolinduced reduction in the median forebrain tissue mass $(\mathrm{f}, \mathrm{g}, \mathrm{h})$. LGE = lateral ganglionic eminence, $\mathrm{MGE}=$ medial ganglionic eminence, $\mathrm{POA}=$ preoptic area. $\mathrm{Bar}$ in $\mathrm{a}=1 \mathrm{~mm}$ 


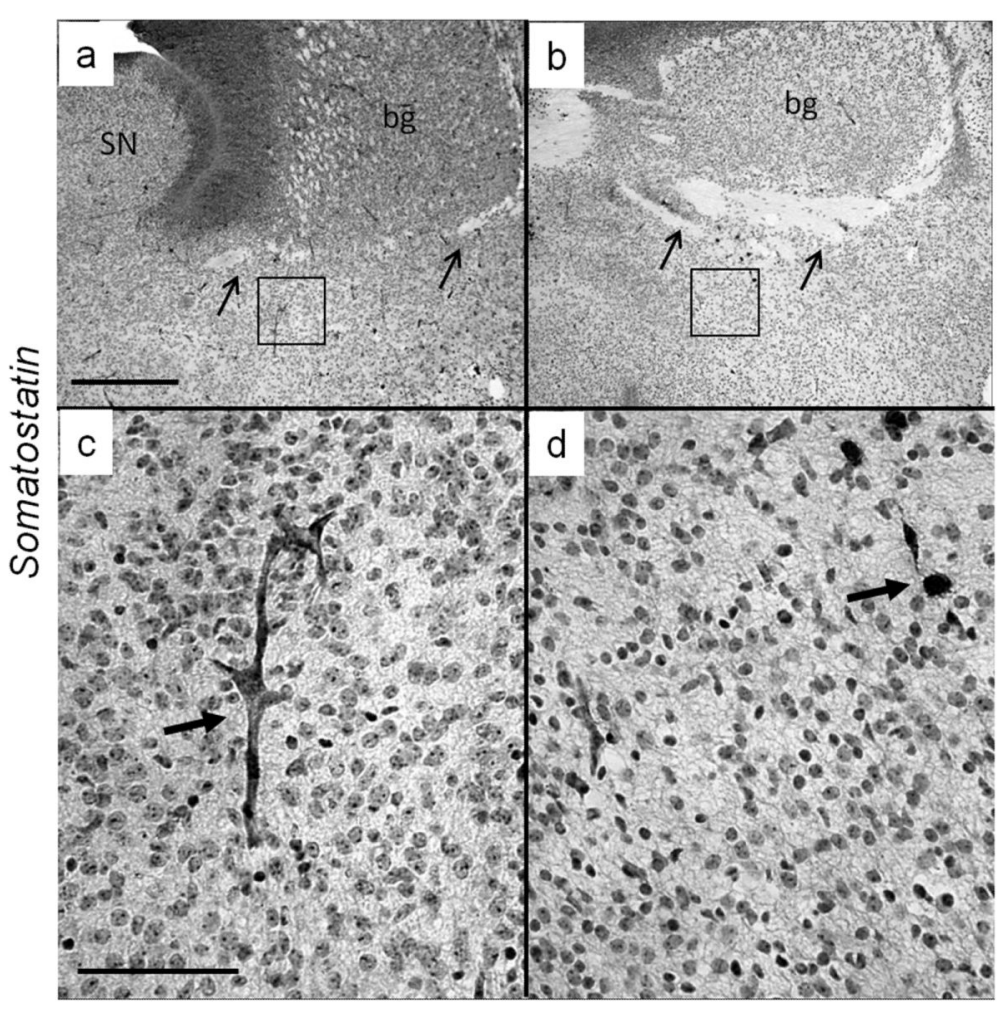

Figure 5.

Shown are representative images of somatostatin (Sst)-immunohistochemical staining in the subpallium of GD 17 mice $(\mathrm{a}, \mathrm{b} ; 10 \mathrm{X})(\mathrm{c}, \mathrm{d} ; 40 \mathrm{X})$. In comparison to a control (a), the basal ganglia (bg) appears small and misshapen and the anterior commissure (arrows) is noticeably thickened in the ethanol-exposed holoprosencephalic fetus (b). High magnification views (boxed area shown in a\&b) illustrate robust Sst-expressing interneurons in the subpallium of the control (c, black arrow). In comparison, the Sst-labeled cells in the ethanol-exposed fetuses appear small and dysmorphic (d, black arrow). $\mathrm{SN}=$ septal nucleus, $\mathrm{bg}=$ basal ganglia. $\mathrm{Bar}$ in $\mathrm{a}=50 \mu \mathrm{m} ; \mathrm{c}=10 \mu \mathrm{m}$ 